\title{
Woody Species Indicator of Soil Fertility and Their Socio-economic Value in the Sudano-guinea Savannahs of Ngaoundere, Adamawa Cameroon
}

\author{
Massai Tchima Jacob ${ }^{1,2, ~ *, ~ I b r a h i m a ~ A d a m o u ~}{ }^{1}$, Ngakou Albert ${ }^{1}$, Babe Ndara Gregoire ${ }^{1}$, \\ Maigari Pale ${ }^{1}$, Mamadou Laminou Mal Amadou ${ }^{1,2}$ \\ ${ }^{1}$ Department of Biological Sciences, Faculty of Science, the University of Ngaoundere, Ngaoundere, Cameroon \\ ${ }^{2}$ Wakwa Research Center, Institute of Agriculture Research for Development, Ngaoundere, Cameroon
}

Email address:

Jacob.massai@yahoo.fr (M. T. Jacob)

${ }^{*}$ Corresponding author

\section{To cite this article:}

Massai Tchima Jacob, Ibrahima Adamou, Ngakou Albert, Babe Ndara Gregoire, Maigari Pale, Mamadou Laminou Mal Amadou. Woody Species Indicator of Soil Fertility and Their Socio-economic Value in the Sudano-guinea Savannahs of Ngaoundere, Adamawa Cameroon. International Journal of Natural Resource Ecology and Management. Vol. 4, No. 6, 2019, pp. 216-223. doi: 10.11648/j.ijnrem.20190406.18

Received: November 25, 2019; Accepted: December 21, 2019; Published: December 31, 2019

\begin{abstract}
In order to identify the woody species indicators of soil fertility according to farmers' perceptions and to determine the socio-economic importance of these woody species, a survey was conducted on one hundred and fifty (150) farmers within the Ngaoundere III $^{\text {rd }}$ Municipality, Adamawa Cameroon. Results indicate that on the seventeen (17) woody species identified by the farmers as soil fertility indicators, six (6) were the most abundant cited whose three (3) mimosaceae (Entada africana, Parkia biglobosa, Albizia zigia), one Combretaceae (Terminalia macroptera), one Clusiaceae (Harungana madagascariensis), and one Myrtaceae (Syzigium guineense var. macrocarpum). These woody species as indicators of soil fertility also played an important role in the socio-economic life of famers because they gave food, sanitary, fodder and are also used to make some kitchen tools or serve as building materials. Vitellaria paradoxa, Parkia biglobosa, Annona senegalensis, Ximenia americana, Ziziphus mauritiana and Piliostigma thonningii were refered as the most diversely used by population of Dang. These results will enable the integration of farmer knowledge in the new technology of the improvement soil fertility and for the farmers to benefice the services given by these woody species.
\end{abstract}

Keywords: Woody Species Indicators, Soil Fertility, Socio-economic Value, Dang, Ngaoundere and Cameroon

\section{Introduction}

Land degradation is one of the constraints of agricultural production that remains the main source of income in subSaharan Africa [1]. This degradation is largely due to the rarity of rainfall and human activities which cause losses of nutrient reserves and soil organic matter [2, 3]. The consequences translate into low yields for major food crops and affect people's food security [4] by the incapability of agricultural production to meet the food needs of an evergrowing population [5].

In Cameroon, particularly in the Far North, although the occupation of the majority of the population is agriculture and livestock, food insecurity problem remains acute because of climate change and loss of soil fertility [6]. In view of the inadequacy of the solutions proposed and imposed on the farming world, researchers are today more unanimous that to must take into account the farmer knowledge in the management of soil fertility [7, 8]. This long-standing knowledge of farmer is based on both biological and physical indicators of the environment $[9,10,11]$. In addition, the integration of this farmer knowledge on soil fertility by inputs of organic fertilizers, as well as the presence of plants improving soil fertility, would be one of the conditions for increasing the potentialities of production $[12,13]$. Promising results have been obtained in this direction in other parts of Africa, particularly in West Africa [7]. However, in Cameroon and especially in the Adamawa region, there are very few studies concerning farmer knowledge on soil fertility, except those of Ibrahima et al. [10, 11] on 
highlighting of the perception, indicators and farmers' strategies of soil fertility management in the Mbe area, Adamawa region of Cameroon. The main objective of this study is to valorize farmers' knowledge of bioindicators, particularly woody species in the agroecological zone of Ngaoundere III $^{\text {th }}$, Adamawa Cameroon. It is through the surveys to determinate the woody species indicators of soil fertility and their socio-economic values according to the farmer's perception in the Sudano-guinea savannahs of Ngaoundere, Adamawa Cameroon..

\section{Material and Methods}

\subsection{Presentation of Study Area}

The study was conducted in the agricultural buffer zones of the humid savannah of Ngaoundere in the Adamawa region of Cameroon. The site is in the Vina Division (Figure 1) along the Ngaoundere-Garoua national highway, $70 \mathrm{~km}$ from Ngaoundere. It lies between $7^{\circ} 35^{\prime}$ and $13^{\circ} 49^{\prime}$ latitude North and between $13^{\circ} 41^{\prime}$ and $13^{\circ} 44^{\prime}$ longitude East. The climate is humid sudano-guinea type with a unimodal rainfall distribution [14]. Mean annual rainfall is about $1500 \mathrm{~mm}$. The rainy season extends from July to September and dry season stretches from November to March [15]. Mean annual temperature is $23^{\circ} \mathrm{C}$ and mean relative annual humidity is $65 \%$ [15]. While Ferralitic soils are the dominant types, with rich clay (40 à 60\%), low organic matter (less than $3 \%$ ), low soil exchange capacity from 15 to $20 \mathrm{meq} / 100 \mathrm{~g}$ and the $\mathrm{pH}$
4.7 to $5.6[16,17]$. Vegetation of Adamawa is a humid savannah type, consisting of shruby and woody savannahs. These savannahs originally populated with Daniellia oliveri and Lophira lanceolata [18]. There were also hydromorphic prairies that were sometimes inundated and contained by Hypparhenia rufa, forest galleries with Syzygium guineense var. guineense and Berlinia grandifolia, degraded fallow lands and savannahs, occasionally used as grazing land, which were composed of Acacia hockii, Afzelia africana [18]. Now, this vegetation is much reduced under the influence of zoo-anthropic factors such as wild fires and rearing $[19,20]$. The population of Adamawa region is about 1015622 with 15.9 inhabitants per $\mathrm{km}^{2}$. This population is cosmopolitan and composed of various tribes that are natives (Boum, Gbaya, Dii) or allogeneic (Fulani, Haoussa, etc..) [21]. Fulani are agropastoralists whereas hunting is very important with the Gbaya. Mboum, Dii, other ethnic groups of the region are mainly agriculturalists, while the Mbororo are nomadic. Agriculture is still traditional. Exploited area are small (as 0.5 to 1 ha). Livestock remains the main economic activity practiced by more than $20 \%$ of the rural population. Other activities like hunting, fishing and crafts are practiced at artisanal scale in the region. The most relevant problems in the region include the permanent decline soil fertility, damages due to Striga on cereals, partridge and ruminants on seedlings and termites on crops as expressed through yellowish and fall down of yam leaves.

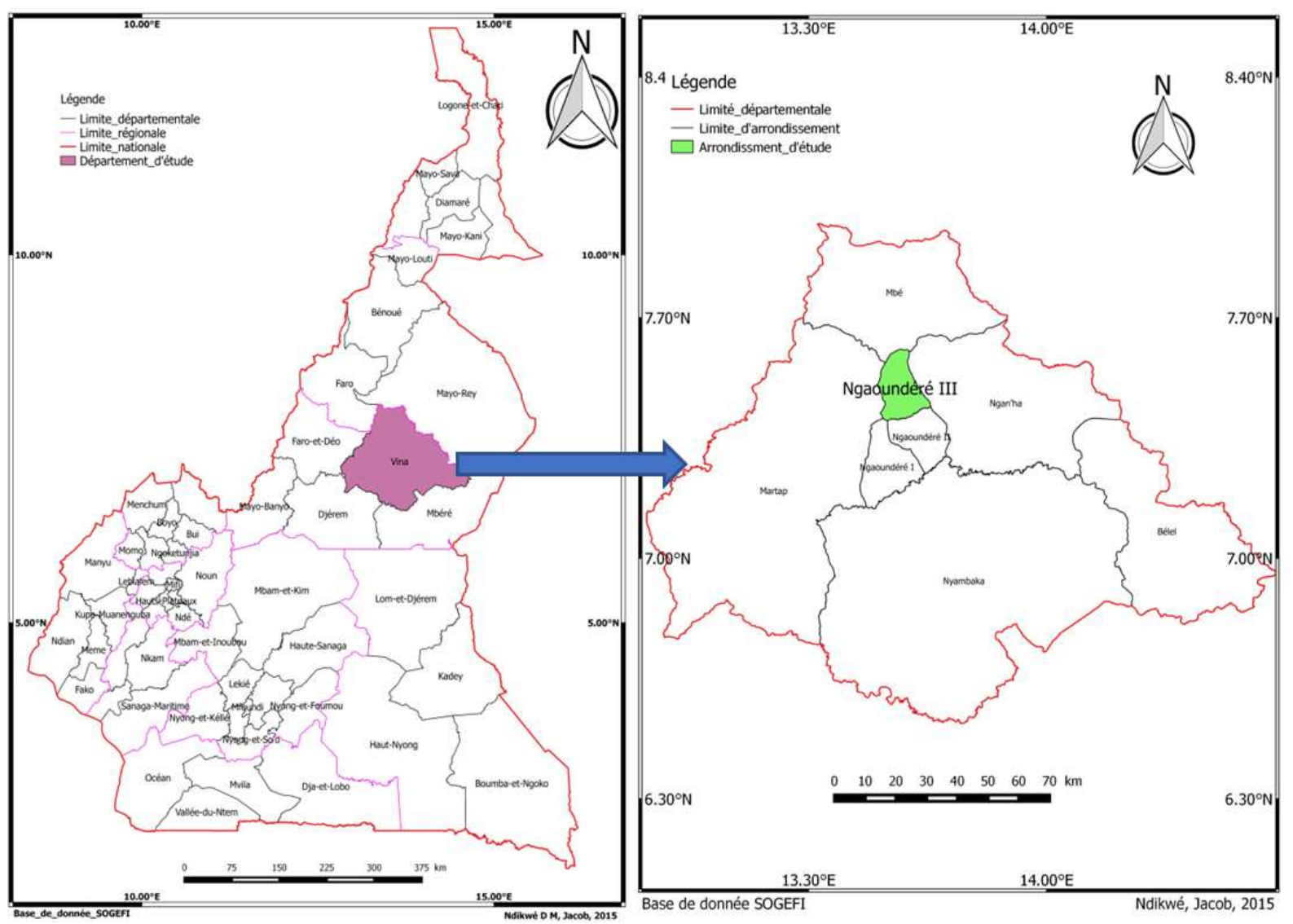

Figure 1. Localization of site study. 


\subsection{Methodology}

\subsubsection{Survey}

Surveys were carried out in three villages of the Ngaoundere III $^{\text {th }}$ subdivision of Vina Division, namely, Gada-Bidou, Borongo and Manwi from Septembre 2017 to January 2018. In each village, a sample of fifty (50) households was constituted. Sample was made up on persons of both sexes and of different ages (Table 1), distributed over the entire population (particularly the indigenous): the fulltime farmers (more than 50\%) and part-time farmers, that is those who associate agriculture to other activities like animal rearing, trade, fishing and teaching. Strangers who have not been leaving up to 10 years in the region were excluded from the sample; because we assumed that, they know little or do not have enough knowledge about the local cultural systems. Sample unit was a farm household with the heads of the households as the respondent. For the survey itself, farmers were interviewed either in their farms or at homes, individually or in groups through a questionnaire with closed questions where they had to answer by yes or no and open questions requesting some comments. The main focus was the farmer's knowledge of plant species indicators of soil fertility and socio-cultural importance of these plant species.

Table 1. Distribution of sex and year in the three localities (\%). Absolute values in parenthesis

\begin{tabular}{llllll}
\hline Parameters & $\begin{array}{l}\text { Gada- } \\
\text { Bidou }\end{array}$ & Borongo & Manwi & Total & Mean \\
\hline $\begin{array}{l}\text { Sample } \\
\text { Sex }\end{array}$ & 50 & 50 & 50 & 150 & \\
Men & $64(32)$ & $74(37)$ & $58(29)$ & & 65.33 \\
Women & $36(18)$ & $26(13)$ & $42(21)$ & & 34.67 \\
Age (year) & & & & \\
{$[25-40]$} & $26(13)$ & $30(15)$ & $40(20)$ & & 32.00 \\
{$[40-60]$} & $50(25)$ & $42(12)$ & $38(19)$ & & 43.33 \\
{$[60-80]$} & $24(12)$ & $28(14)$ & $22(11)$ & & 24.67 \\
\hline
\end{tabular}

\subsubsection{Data Analysis of Survey}

The degree of knowledge and the rate of responses of woody species indicators of soil fertility were calculated through the number of answer of surveyed farmers and the total sample of farmers.

The index of utilization (IU) for each species was calculated from the sum of the average utilization scores of its organs according to the following formula [22, 23]:

$$
\mathrm{IU}=\sum\left(1 / \mathrm{N} \sum_{i=1}^{3} s i\right)
$$

Where IU is the index of utilization, $\mathrm{N}$, the number of people surveyed, $\mathrm{Si}$ the score attributed to the use of the organ of the species by each respondent, $\mathrm{Si}=\{1,2,3\}$.

\section{Results}

Figure 2 shows the degree of knowledge of woody species indicators of soil fertility by the populations of the three villages surveyed. The knowledge of the populations of the three villages varied from $22.66 \%$ in Gada-Bidou to $27.33 \%$ in Borongo according to the farmer answers, with an overall average of $24.88 \%$. The populations of the three villages have a fairly similar degree of knowledge, but slightly higher in Borongo. In general, the degree of knowledge of populations about soil fertility-indicator species is mainly due to the endogenous knowledge that producers have acquired for a long time about the quality of their soil.

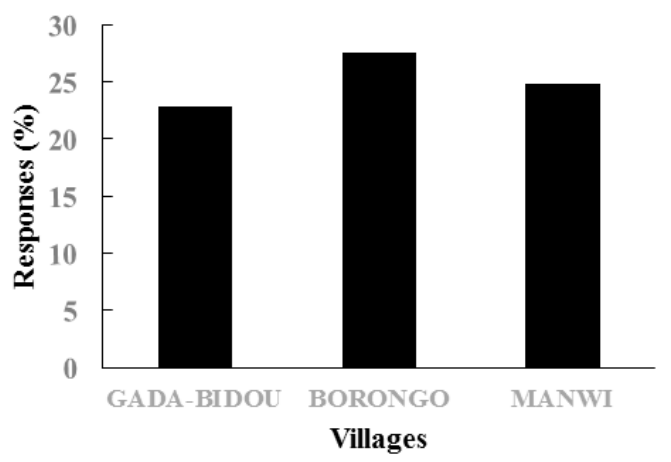

Figure 2. Degree of knowledge of woody species indicators of soil fertility in the three surveyed villages of the Sudano-guinea savannahs of Ngaoundere, Cameroon.

The woody species indicator of soil fertility cited by farmers are seventeen (17), grouped into thirteen (13) families, the most dominant in number was the family of Mimosaceae, with four species (Table 2). The most cited families are Combretaceae $(20.66 \%$ of responses) and Mimosaceae $(20.65 \%)$. The main indicator species of soil fertility according to the farmers are six (6). These are Terminalia macroptera (20.66\%), Entada africana (7.33\%), Parkia biglobosa (6.66\%), Harungana madagascariensis (6.66\%), Syzigium guineense var. macrocarpum (6.66\%) and Albizia zigia (5. 33\%). Vitellaria paradoxa, which benefits from $4.66 \%$ of farmers' responses, can be added to this group. Among these six species, we noted a broad dominance of Terminalia macroptera (20.66\% of responses). The low number of woody species indicator of soil fertility recognized by the farmers of the localities of Dang could be explained by the fact that the farmers generally rely on various indicators such as herbaceous plants and physical quality of the soil, to appreciate the fertility of their soil.

Table 2. Woody Indicator of Soil Fertility according to Farmer's Perception.

\begin{tabular}{|c|c|c|c|}
\hline Families & Species & Local name & Responses (\%) \\
\hline Annonaceae & Annona senegalensis Pers. & doukouhi laddé & 3.33 \\
\hline Clusiaceae & Harungana madagascariensis Lam ex Poir. & Bourouhi & 6.66 \\
\hline Caesalpiniaceae & Piliostigma thonningii Milde Redhae & Barkehi & 0.66 \\
\hline & Terminalia glaucescens Planch. & Koulahi & 1.33 \\
\hline
\end{tabular}




\begin{tabular}{lll}
\hline Families & Species & Local name \\
\hline Fabaceae & Detarium microcarpum Guill. \& Perr. & Responses (\%) \\
Mimosaceae & Albizia zigia J. F. Macbr. & Bougainahi \\
& Entada africana Guill. \& Perr. & Narehi \\
& Parkia biglobosa (Jacq.) R. Br. ex G. Don & 5.33 \\
& Acacia polyacantha Willd. & 7.33 \\
Myrtaceae & Syzigium guineense var. macrocarpum (Engl.) F. White & Assora \\
Olacaceae & Ximenia americana L & Tsaboulhi \\
Ochnaceae & Lophira lanceolata Van Tiegh. ex Keay & Saktahi \\
Rhamnaceae & Ziziphus mauritiana Lam & Djaabi \\
Sapotaceae & Vitellaria paradoxa C. F. Gaertn. & Karehi \\
Verbenaceae & Vitex doniana Sweet & Galbihi \\
& Vitex madiensis Oliv. & Galbihi \\
\hline
\end{tabular}

The socio-economic importance of woody species indicator of soil fertility varied with the type of use according to the farmer perception. In the study area, these species have multiple uses because they are used in food, traditional medicine, artisanal service, fodder and beekeeping (Table 3 ). The main species which have a high utilization index in human nutrition, for their fruits and seeds are Vitellaria paradoxa, Parkia biglobosa, Lophira lanceolata and Ziziphus mauritiana or for their fruits are Annona senagalensis, Syzigium guineense var. macrocarpum, Vitex doniana and Ximenia americana. However, these use index values are higher in species whose seeds and fruits are used. Their fruits are consumed in various forms and the easy access and the taste of these fruits would be at the base of the choice of these species by farmers. The pulp of the fruit of Parkia biglobosa is turned into powder for consumption directly or in the form of cakes and its seeds are used in cooking as a condiment called "Daddawa" to replace the cube Maggie. The fruit of Vitellaria paradoxa is consumed directly and its seed is used to make shea butter which is used in cooking and in hair cosmetics. The fruit of Vitex madiensis and Detarium microcarpum, and the fruits and seeds of Lophira lanceolata are also prized by population and consumed directly. As for the fruits and seeds of Ziziphus mauritiana, they are eaten directly by farmer or in the form of cake despite the small presence of this species in this locality. In the savannahs of Adamawa these species play an important role in feeding of pulations of Northen Cameroon.

Table 3. Index of Utilization (IU) of Indicator Species of soil fertility in Various Socio-Economic

\begin{tabular}{|c|c|c|c|c|c|c|}
\hline Species & Food & Pharmacopoeia & Fodder & Artisanal & Beekeeping & Total IU \\
\hline Annona senegalensis & 2.93 & 4.56 & 1.09 & 1.21 & 1.67 & 11.48 \\
\hline Harungana madagascariensis & 0.13 & 3.59 & 0.07 & 4.39 & 1.15 & 9.3 \\
\hline Piliostigma thonningii & 0.27 & 5.02 & 5.17 & 2.28 & 1.13 & 13.86 \\
\hline Terminalia macroptera & 0.00 & 2.89 & 2.00 & 2.13 & 1.11 & 8.14 \\
\hline Terminalia glaucescens & 0.00 & 2.90 & 3.32 & 1.09 & 1.09 & 8.41 \\
\hline Detarium microcarpum & 2.13 & 2.81 & 1.09 & 1.18 & 1.07 & 8.28 \\
\hline Albizia zigia & 0.00 & 2.27 & 2.69 & 2.23 & 1.05 & 8.25 \\
\hline Entada africana & 0.00 & 1.93 & 2.16 & 1.17 & 1.05 & 6.32 \\
\hline Parkia biglobosa & 5.95 & 2.70 & 0.67 & 2.15 & 1.13 & 12.60 \\
\hline Acacia polyacantha & 0.00 & 0.07 & 1.35 & 0.67 & 1.07 & 3.15 \\
\hline Syzigium guineense var. macrocarpum & 2.94 & 2.50 & 0.13 & 0.53 & 1.17 & 7.27 \\
\hline Ximenia americana & 3.95 & 4.72 & 0.10 & 1.11 & 1.12 & 11.01 \\
\hline Lophira lanceolata & 4.01 & 2.08 & 0.09 & 1.08 & 1.17 & 8.44 \\
\hline Ziziphus mauritiana & 3.33 & 3.38 & 3.87 & 1.07 & 1.13 & 12.77 \\
\hline Vitellaria paradoxa & 5.93 & 3.21 & 1.14 & 2.19 & 1.47 & 13.94 \\
\hline Vitex doniana & 2.94 & 1.83 & 1.09 & 1.16 & 1.22 & 8.24 \\
\hline Vitex madiensis & 2.07 & 1.67 & 0.16 & 1.06 & 1.11 & 6.07 \\
\hline
\end{tabular}

For fodder, the leaves and pods of woody plants are the main parts which are edible by livestock. According to the population, in the dry season pods and young leaves or woody buds are much prized by livestock because they constitute supplementary foods during the famine period. Several woody species are edible by animals, but among the indicator species of soil fertility, those who are highly consumed are Albizia zygia and Entada africana for their leaves and Piliostigma thonningii, Terminalia glaucescens, Parkia biglobosa and Ziziphus mauritiana for their leaves and pods. The leaves of Albizia zygia and Entada africana are freely consumed by all livestock of the locality. The leaves and fruits of Ziziphus mauritiana are eaten by cattle, sheep and goats, but their fruits are more appetized by goats. The leaves of Parkia biglobosa are eaten by cattle, sheep and goats and their pods, fruits and seeds by goats. The pods of Terminalia glaucescens and Piliostigma thonningii are consumed as natural meal by cattle in the dry season, but the most edible pods by cattle are those of Piliostigma thonningii.

The manufacture of hunting equipment, fishing, kitchen utensils and constructions is also ensured also by the woody species indicators of soil fertility through their leaves, branches, trunks and saps. Nevertheless the most used parts are the trunk and the branches. Trees are more used in these services than shrubs. These results show that soil fertility 
indicator plants play also various roles in the artisanal services of the population. In our study area, among the indicator species of soil fertility the most used in the artisanal services of the populations are Harungana madagascariensis, Piliostigma thonningii, Albizia zigia, Terminalia macroptera, Parkia biglobosa and Vitellaria paradoxa. The sap of Harungana madagascariensis is used as a colourant on twigs for the manufacture of mats. The dry fruits of Piliostigma thonningii are also used as varnish. The branches and trunks of Albizia zigia, Terminalia macroptera and Parkia biglobosa are used for the construction of fences, hangars, huts and cooking tools. The trunk of Entada Africana, Terminalia glaucescens, Detarium microcarpum, Ziziphus mauritiana, Acacia polyacantha are used by farmers to make hoes, turn couscous and other cooking tools.

The medicinal value is ensured by the roots, leaves, barks and some rare fruits. However leaves and bark are the most used parts. All species identified as soil fertility indicators have medicinal value, but their degree of use depends on the population. The highly used species among the seventeen are Piliostigma thonningii, Harungana madagascariensis, Annona senagalensis, Ziziphus mauritiana, Ximenia americana and vitellaria paradoxa. The leaves of Piliostigma thonningii are used for the treatment of colds and eyes problems. Its barks are used for toothache and ears, and the boiled roots of this especies are used in the treatment of cough, stomach ache, and rheumatism and to heal wounds. The bark and leaves of Harungana madagascarienis are used in the treatment of painful menstruation, its leaves mixed with those of Bidens pilosa treats typhoid. The leaves and bark of Syzigium guineense var. macrocarpum are used for the treatment of diarrhea and stomac haches of women. The bark of Ziziphus mauritiana is used to treat hemorrhages after childbirth and its young leaves eaten directly or boiled mixed with its barks are used against stomach aches. Farmers use the fruits of Ximenia americana to calm the constipation and the decoction of its roots cure the fever and the diarrhea, the juice obtained after extraction of its leaves treats the infections, its barks are used for the skin problems. The boiled roots of Annona senagalensis fight against amoebic dysentery while others farmer use its bark combined with Ageratum conizoides for the treatment of diarrhea, its leaves are used against yellow fever. Its roots are used as an antidote against the venoms of scorpions and reptiles.

All the indicator species mentioned by the farmers have a medicinal value according to the population, except Acacia polyacantha, which only one farmer has been able to bring out its medicinal value. The leaves of Terminalia macroptera are used against fever, its barks against dysentery. The leaves of Albizia zigia are used for the treatment of pain and fever, while its roots are used in the treatment of tuberculosis. The mixture of leaves and barks of Detarium macrocarpum are used to treat meningitis and others farmer use these leaves only to treat malaria. The bark of Parkia biglobosa is used as mouthwash and by inhalation for headaches and for cleaning teeth, his barks and leaves are macerated in baths to treat leprosy and malaria. The shea butter obtained from the seeds of Vitellaria paradoxa is also valued in medicine, it is used to relieve rheumatism, applied to accelerate the healing of wounds and prevent infections. The leaves and roots of Vitex doniana have antiseptic properties and its fruit is used in the treatment of diarrhea. Their leaves and barks are used by population in the treatment of several human diseases like diarrhea, chickenpox, toothache and leprosy. The bark and roots of Entada africana in decoction cure inflammatory problems. Boiled crushed barks of Terminalia glaucescens are used for the treatment of malaria, fever and the treatment of bacterial infections. Lophira lanceolata is used in the treatment of several diseases. Its bark and roots are used in the treatment of headaches, dysentery and abdominal pain. The bark of Vitex madiensis is used for the treatment of toothaches and fever.

In beekeeping, all these species are pollinated by bees, but they are all poorly used. According to the population, the species which are strongly used in beekeeping are those whose color of flowers attracts bees and that it requires more observation to identify these species.

In sum, the species, which have the highest total utilization index, are Vitellaria paradoxa, Parkia biglobosa, Annona senegalensis, Ximenia americana, Ziziphus mauritiana, and Piliostigma thonningii.

\section{Discussion}

Farmers of the Dang are well aware of the concept of soil fertility. This concept is reflected in their expressions through the survey. The populations of the three villages surveyed have a fairly similar degree of knowledge, but slightly higher in Borongo. Other studies like those of Akpo et al. [24] have also shown that the knowledge of farmers' soil bioindicators does not vary between ethnic groups in the Okpara Basin in Benin. On the other hand, Bio-lafia [25] reported contrary results. According to him, the soil classification criteria are specific to each ethnic group in the region [25]. In general, the degree of knowledge of populations about soil fertility indicator species is mainly due to the endogenous knowledge that producers have acquired for a long time about the quality of their soil as reported by soumana [7] in his studies on agricultural indicators of soil fertility in Mali [7]. This farmer knowledge of soil fertility is done by indicators most commonly used is the yield of agricultural production which varies according to the plant species introduced into a field, and especially thanks to the difference in performance obtained under and outside of crown of a given indicator species [24].

Among these six species, who are very indicated as soil fertility species we note a broad dominance of Terminalia macroptera (20.66\% of responses) and this result have been mentioned in the previous studies of Ibrahima et al $[10,11]$ that reported farmer responses for this species of $11.39 \%$ in the locality of Mbe and $29.29 \%$ in the department of Djerem $[10,11]$. Except the Mimosaceae known as legumes and having a fertilizing power, Harungana madagascariensis and Syzigium guineense var. macrocarpum also appear as 
important soil fertility species with have the same response of $6.66 \%$. Other studies have showed that Harungana madagascariensis improves the fertility of acid soils [26] Research done by Mapomgmetsem reported that Syzigium guineense var. macrocarpum is an indicator species of soil fertility in the Adamawa region [27]. In addition, the species poorly mentioned in our study have been recognized in other regions as the main indicators of soil fertility. Indeed, Acacia polyacantha has been identified as an indicator species of soil fertility by the populations of Mbé locality [10]. In the same order of idea Vitellaria paradoxa and Parkia biglobosa are been mentioned as bioindicators of soil quality in the Okpara Basin in Benin [24]. The indicator value of soil fertility of these non-leguminous species could be explained by the perception of the population on soil quality and crown yield due to the presence of these species in their fields. Concerning the plant families used as indicators of soil fertility, our findings reveal that combretaceac take the first place $(20.66 \%$ of responses) followed by mimosaceae (20.65\% of responses). Likewise, other works done in Mbe localaly, have obtained concerning this variation that the poaceae take the first place (39\% of the total responses), followed by the mimosaceae $(21.73 \%)$ and combrataceae $(17.00 \%)$ [10].

The low number of woody species indicator of soil fertility recognized by the farmers of the localities of Dang could be explained by the fact that the farmers generally rely on various indicators such as herbaceous plants and physical quality of the soil, to appreciate the fertility of their soil [8, 11]. Indeed, herbaceous plants such as Commelina benghalensis were also cited by farmers as indicators of soil fertility in northern Cameroon and Mbé respectively [9, 10]. Except woody and herbaceous plants, farmers appreciate also the fertility of their soil by using physical characters such as color and type of soil, appearance of fauna like eartworms and snail $[10,8,11]$.

The diversity of socio-econimic value of woody species indicators of soil fertility that we are finding vary according to the locality and their use according to each farmer. These species are very used in the feeding of population in the savannahs of Adamawa. Mapongmetsem et al. [28] have indicated that these species play an important role in feeding of populations of Northen Cameroon. The main fruit species identified among these indicator species of soil fertility in our study are among the most consumed of West African savannahs especially in Burkina-Faso as demonstrated by Koadima [29].

Among these indicators species of soil fertility, families that are very used in fodder are Mimosaceae (Albizia zygia, Entada africana and Parkia biglobosa). Findings of the research carried out by Guerin [30] also show that the young leaves of the Mimosaceae constitute the supplementary fodder during the dry season for ruminants [30]. In our results, we found also that the fruits or pod of Ziziphus mauritiana, Terminalia glaucescens and Piliostigma thonningii are consumed as natural meal by cattle in the dry season, but the most edible pods by cattle are those of
Piliostigma thonningii. These results are similar to the works carried out in the locality of Wakwa who reported that $19.35 \%$ of woody species were freely comzumed on the cattle route, but the most prized is Piliostigma thonningii (37\%) [31]. According to this author, woody plants which have a potential for milk production are Piliostigma thonningii, and Albizia zygia.

More than a half of farmers in the Dang used woody species indicators of soil fertility in artisanal services but the use more trees than shrubs. These results show that soil fertility indicator plants play also various roles in the artisanal services of the population. Wild plants play a major role in the crafts of pygmies "Mbuti" in the Democratic Republic of Congo as indicated by Kahindo et al. [32]. Among the most used species in this service, species who has a higher value in artisanal service is Harungana madagascariensis. We found that some farmers use this specie to make huts, hoes and turn couscous, the sap of this species is very used as a colourant on twigs for the manufacture of mats as already mentioned by Orwa et al. [26]. All other woody species indicator of soil fertility are used for the construction of fences, hangars, huts and to to make hoes, turn couscous and cooking tools and this could be expalined by their abundance in this locality.

All the woody species indicators of soil fertility are generally used in medecine simillary by the farmers interviewed in areas of study, because they are available in large quantities and spreading aroung these localities. Many research done in Africa have also indicated the similar medecine value like that we are found, this may be explained by the fact that these species are more spreading in Africa. The roots of Piliostigma thonningii are used in Ethiopia to treat rheumatism and intestinal problems [33]. Farmers of Dang use Ximenia americana for skin problem, In Mali, populations use the roots and barks of Ximenia americana to treat skin problems [34]. Other works have also demonstrated that some populations of Enugu state in Nigeria use the leaves of Annona senagalensis to treat yellow fever and tuberculosis, and its roots are used as an antidote against the venoms of scorpions and reptiles [35]. Dang farmers use the leaves of Terminalia macroptera against fever, its barks against dysentery. Similar results were obtained by Arbonnier [36] who reported that some populations in West Africa use the leaves of this species to treat fever and tuberculosis [36]. Concerning Vitellaria paradoxa, other work reveals that the shea butter obtained from the seeds of Vitellaria paradoxa is also valued in medicine; it is used to relieve rheumatism, applied to accelerate the healing of wounds and prevent infections. Shea butter helps also to treat rheumatism [37] Medecine value of Terminalia glaucescens obtained in the Dang locality corroborates those of Konan et al. [39] who discover that a solution extracted from the preparation of the bark of Terminalia glaucescens allows the rats to resist against bacterial germ [39]. Some studies in Africa have also shown the same medecine value of certain species that we are elucitade in the Dang. Study of Arbonnier [36] reported that the populations of several West African countries use the 
leaves and barks of Vitex doniana in the treatment of diarrhea, chickenpox, toothache, leprosy, smallpox and hypertension [38]. Lophira lanceolata is also used in the treatment of several diseases such as headaches, dysentery, abdominal pain, diarrhea and certain cardiovascular diseases [40].

In sum, the results concerning the highest total utilization index obtained on these woody species indicators of soil ferility are related to those of Guigma et al. [41] who reported that in southern Burkina Faso, Vitellaria paradoxa, Parkia biglobosa and Annona senegalensis are the species which have a high total utilization [41].

\section{Conclusion}

The farmers of the locality of Dang have a good enough knowledge of the soil fertility according to their own indigenous system based on the experience transmitted by the generations in generations. They used biological indicators, in particular the woody species that allowed them to apreciate the fertility of soil. In fact, several woody species have identified by the population of Dang as soil fertility indicators but seven are most mentioned by farmers. These woody species indicators of soil fertily have sereval importances in socio-economic plan of population. According to each farmer and to their utilization index, these species are source of food, sanitary, fodder and are used in several artisanal services. Therefore, the modifications, the adaptations or the new techniques of introduction of these species in the agroforestery systems are necessary. Such modifications should hold in account the rationality and the knowledge of the farmers.

\section{References}

[1] FAO., 2003. Gestion de la fertilité des sols pour la sécurité alimentaire en Afrique subsaharienn. Rome. Italie, 63 p.

[2] Bationo A. and Buerkert A. 2001. Soil Organic carbon measurement for sustainable land use in Sudano-Sahelian West Africa. Nutr. Cycl. Agroecosys, 61: 131-142.

[3] Orou Séko R., 2013. Contribution à la restauration des sols agricoles dans la commune de Banikoara. Diplôme d'Etude Approfondie, Facultédes Lettres, Arts et Sciences Humaines, Université d'Abomey-Calavi, Bénin, 92p.

[4] Moussa M. Boubacar, Diouf A., Abdourahamane S. I., Jangorzo N. S., Mahamane A., Axelsen J. A. and Ambouta J. M. K. 2015. Soil Physicochemical Characteristics Under Different Ecosystems in Western Niger. Int. J. Curr. Microbiol. App. Sci., 4: 375-383.

[5] FAO, 1999. Synthèse agronomique des essais de fertilisation dans la République Démocratique du Congo. CD-ROM, division de la mise en valeur des terres et des eaux Fao viale delle terme de caracalla. Rome.

[6] Mapongmetsem, P. M., 2005. Phénologie et apports au sol des substances biogènes par la litière de quelques fruitiers sauvages des savanes soudano- guinéennes. Thèse de Doctorat d 'Etat, Universite de Yaounde I., pp: 242.

[7] Soumana I. 2000. Indicateurs biologiques paysans de la fertilité du sol au Niger. In: Floret Ch. and Pontanier R. (Eds). La jachère en Afrique tropicale, John Libbey, Paris, pp: 103110 .

[8] M'Biandoun M. and Bassala J-P. O., 2007. Savoir paysan et fertilité des terres au Nord-Cameroun. Cahiers Agricultures 16,3 .

[9] M'Biandoun M, Guibert H and Olina JP. 2003. Caractérisation de la fertilité du sol en fonction des mauvaises herbes présentes. In: Jamin JY, Seiny Boukar L, Floret C. (eds). Savanes africaines: des espaces en mutation, des acteurs face à de nouveaux défis. Actes du colloque, mai 2002, Garoua, Cameroun. PRASAC, N'Djamena, Tchad - CIRAD, Montpellier, France.

[10] Ibrahima A., Nguetnkam J. P., Pabame P., Tchimbi B. and Guidawa Gonlaina D., 2007. Soil Degradation in the Sudanoguinea Savannas of Mbe, Cameroon: Farmers' Perception, Indicators and Soil Fertility Management Strategies. Research Journal of Agriculture and Biological Sciences, 3 (6): 907916.

[11] Ibrahima A., Souhore P., Hassana B. and Babba H. 2017. Farmers' perceptions, indicators and soil fertility management strategies in the sudano-guinea savannahs of Adamawa, Cameroon. International Journal of Development and Sustainability, 6 (12): 2035-2057.

[12] De Groote JJ, Soumaré A, Koné D, Radersma S et De Vos JA. 1998. Utilisation des éléments nutritifs et de l'eau par des ligneux. In: Breman H. et Sissoko K. (Eds). L'intensification agricole au sahel. AB-DLO, Wageningen et IER Bamako, pp. 225-241.

[13] Rahman S. 2003. Environmental impacts of modern agricultural technology diffusion in Bangladesh: an analysis of farmers' perceptions and their determinants. Journal of Environmental Management, 68: 183-191.

[14] Suchel J. B., 1971. La répartition des pluies et régimes pluviométriques au Cameroun. Centre de Recherches Africaines, Université fédérale du Cameroun.

[15] Collins A, 1985. Flash géographique. Le Cameroun. Editions clé. Yaoundé. 118 p.

[16] Boutrais J., 1998. L'agro-élevage des Foulbé de Ngaoundéré (Adamaoua camerounais). Les évolutions des relations entre l'agriculture et l'élevage. In: Actes de l'Atelier CIRAD, 5-6 mai, 1998, Montpellier, pp: 107-120.

[17] Brabant P. and Humbel F. X., 1974. Notice explicative de la carte pédologique de Poli, $\mathrm{n}^{\circ} 51$, Carte au 1/50000e, Yaoundé.

[18] Letouzey R., 1968. Etude phytogéographie du Cameroun. Ed. Paul Le Chevalier. Paris France. 551p.

[19] Yonkeu S., 1993. Végétation des pâturages de l'Adamaoua, Cameroun: écologie et potentialité pastorale. Thèse de Doctorat, Université de Rennes I (sciences biologiques), France, 207p.

[20] Mapongmetsem P. M., Kapchie V. N., and Tefempa B. H., 2012. Diversity of local fruit trees and their contribution in sustaining the rural livelihood in the northern Cameroon. Ethiopian Journal of Environmental Studies and Management, 5 (1): 32-46. 
[21] Anonymous, 1994. Diagnostic général de la situation de l'environnement dans la province de l'Adamaoua. Elaboration du plan national de gestion de l'environnement au Cameroun. Document de base, MINEF, GTZ, pp: 143.

[22] Evert T., Ina V and Van Damme P., 2009. Valuation of forest and plant species in indigenous territory and national park Isiboro-Sécure, Bolivia. Economic Botany, XX, X: 1-13.

[23] Monteiro J. M., Albuquerque U. P. d., Lins-Neto E. M. de Araujo E. L. and Amorim E. L., 2006. Use patterns and knowledge of medicinal species among two rural communities in Brazil's semi-arid northeastern region. J. Ethnopharmacol. 105: 173-186.

[24] Akpo M., Saïdou A., Yabi I., Balogoun I. and Bio Bigou L. B., 2016. Indicateurs paysans d'appréciation de la qualité des sols dans le bassin de l'Okpara au Bénin. Etudes et gestion des sols, 23: 53-64.

[25] Bio-lafia., 2007. Appréciation de la qualité des sols à travers la diversité des pratiques culturales cas du village de Gounin, Commune de N'Dali. Mémoire pour l'obtention du Diplôme d'Ingénieur des Travaux (DIT) Université d'Abomey Calavi, Bénin. $45 \mathrm{p}$.

[26] Orwa C, Mutua. A., Kindt R., Jamnadass R. and Anthony. S., 2009. Agroforestry Database: a tree reference and selection guide version 4.0. pp 1-5.

[27] Mapongmetsem P., 2000. Jardins de case et domestication dans les trophiques: cas des savanes humides du Cameroun (Adamaoua). Com. ICRAF. Agroprolis international, 12p.

[28] Mapongmetsem, P. M., Tchiégang, C., Nkongmeneck, B. A., Kapseu, C. and Kayem, G. J., 1997. Agroforestry potentials of the indigenous tree species in the northern Cameroon. Cam. Biol. Bioch. Sci., 7 (1): 21-25.

[29] Koadima M., 2008. Inventaire des espèces ligneuses utilitaires du Parc W et terroirs riverains du Burkina Faso et état des populations de trois espèces à grande valeur socioéconomique. Mémoire de Diplôme de DEA, Université d'Ouagadougou, Laboratoire de Biol. et Ecol. Végét. 56 p.

[30] Guérin A, 1989. Note bibliographique sur les fourrages ligneux: rôle dans les systèmes pastoraux ou agropastoraux, productivité, valeur alimentaire. In: Acte de séminaire régional sur le fourrage et l'alimentation des ruminants $d u 16$ au 20 novembre 1987 à Ngaoundéré (Cameroun) Tome 1. PP.331-345.

[31] Biba Hamadou P., 2014; Caractérisation des pâturages de la station fourragère de Wakwa (Adamaoua, Cameroun). Mémoire de Master Faculté des sciences. Université de
Ngaoundéré pp: 48-58.

[32] Kahindo M., Lejoly. J and Mate. M., 2001. plantes sauvages a usages artisanaux chez les pygmés «Mbuti» de la foret de l'Ituri en RDC. Tropicultura, 19, 1 28-332p.

[33] Bekele-Tesemma A., Birnie A and Tengnas B., 1993. Useful trees and shrubs for Ethiopia. Regional Soil Conservation Unit (RSCU), Swedish International Development Authority (SIDA).

[34] Diallo D., Sogn C., Samake FB, Paulsen BS, Michaelsen T. E. and Keita A., 2002. Wound Healing Plants in Mali, the Bamako Region. An Ethnobotanical Survey and Complement Fixation of Water extracts from Selected Plants. Pharm. Biol., 40: 117-128.

[35] Aiyeloja A. and Bello O., 2006. Ethnobotanical Potentials actions, biochemical and physiological effects of Common Herbs in Nigeria: A Case Study of State, Edu. Res. Rev., 1 (1): 16-22.

[36] Arbonnier M., 2004. Trees, shrubs and Lianas of West Africa Dry Zones. Margraf Publishers, Weikersheim.

[37] Moore S., 2008. The role of Vitellaria Paradoxa in poverty reduction and food security in the Upper East region of Ghana. Earth \& Environment 3: 209-245.

[38] Arbonnier M., 2000. Arbres, arbustes et lianes des zones sèches d'Afrique de l'Ouest. CIRAD/MNHN/UICN.539p.

[39] Konan F., Guessennd N., Koffi K. E., Adjogoua E., AllangbaAtsain M. R., Kouakou K. L., Koffi K. L. and Dosso M., 2016. Terminalia glaucescens Planch. ex Benth. (Combretaceae), a Medicinal Plant of Côte-d'Ivoire Pharmacopoeia: Antibacterial Activity on Staphylococcus and Pseudomonas, Acute Toxicity on Mice and Lethal Effect on Vero E6 Cells. International journal of pharmacy and pharmaceutical research, 7: 290-303.

[40] Kouakou Kouakou L., Bléyéré Nahounou M., Oussou N'Guessan J.B., Konan Brou A., Amonkan Kouao A., Abo Kouakou J.C., Yapo Angoué P. and Ehilé Ehouan E., 2013. Effects of leaf decoction from Lophira lanceolata Tiegh. ex. Keay (Ochnaceae) on arterial blood pressure and electrocardiogram in anesthetized rabbits. The pharma innovation journal, 2 (9): 2277- 7695.

[41] Guigma Y, Zerbo P. and Millogo-Rasolodimby J., 2012. Utilisation des espèces spontanées dans trois villages contigus du Sud du Burkina Faso. Tropicultura, 30 (4): 230-23. 